\title{
Ketone Body Transport in the Human Neonate and Infant
}

\author{
P. F. Bougneres, C. Lemmel, P. Ferré, and D. M. Bier \\ U 188 Institut National de la Santé et de la Recherche Médicale, Pediatric Endocrinology, Hôpital Saint Vincent de Paul, 7 SO14 Paris; \\ Centre de la Nutrition du Centre National de la Recherche Scientifique, Meudon-Bellevue; Metabolism Division, Washington University
} School of Medicine, St. Louis, Missouri 63110

\begin{abstract}
Using a continuous intravenous infusion of $D-(-)-3-h y-$ droxy $\left[4,4,4-{ }^{2} \mathbf{H}_{3}\right]$ butyrate tracer, we measured total ketone body transport in 12 infants: six newborns, four 1-6-mo-olds, one diabetic, and one hyperinsulinemic infant. Ketone body inflow-outflow transport (flux) averaged $17.3 \pm 1.4 \mu \mathrm{mol} \mathrm{kg}{ }^{-1} \mathrm{~min}^{-1}$ in the neonates, a value not different from that of $20.6 \pm 0.9 \mu \mathrm{mol} \mathrm{kg}^{-1}$ $\mathrm{min}^{-1}$ measured in the older infants. This rate was accelerated to $32.2 \mu \mathrm{mol} \mathrm{kg}^{-1} \mathrm{~min}^{-1}$ in the diabetic and slowed to $5.0 \mu \mathrm{mol}$ $\mathrm{kg}^{-1} \mathrm{~min}^{-1}$ in the hyperinsulinemic child. As in the adult, ketone turnover was directly proportional to free fatty acid and ketone body concentrations, while ketone clearance declined as the circulatory content of ketone bodies increased.

Compared with the adult, however, ketone body turnover rates of 12.8-21.9 $\mu \mathrm{mol} \mathrm{kg} \mathrm{kin}^{-1} \mathrm{~min}^{-1}$ in newborns fasted for $<8$ $h$, and rates of 17.9-26.0 $\mu \mathrm{mol} \mathrm{kg} \mathrm{min}^{-1}$ in older infants fasted for $<10 \mathrm{~h}$, were in a range found in adults only after several days of total fasting. If the bulk of transported ketone body fuels are oxidized in the infant as they are in the adult, ketone bodies could account for as much as $\mathbf{2 5 \%}$ of the neonate's basal energy requirements in the first several days of life.

These studies demonstrate active ketogenesis and quantitatively important ketone body fuel transport in the human infant. Furthermore, the qualitatively similar relationships between the newborn and the adult relative to free fatty acid concentration and ketone inflow, and with regard to ketone concentration and clearance rate, suggest that intrahepatic and extrahepatic regulatory systems controlling ketone body metabolism are well established by early postnatal life in humans.
\end{abstract}

\section{Introduction}

In addition to producing glucose at the rate of about $9 \mathrm{~g} \mathrm{~kg}^{-1}$ $\mathrm{d}^{-1}(1)$, the human newborn develops accelerated lipid mobilization from its large fat stores (2) in order to meet energy requirements. The release of fatty acids from adipose tissue occurs at a rate of $\sim 4-5 \mathrm{~g} \mathrm{~kg}^{-1} \mathrm{~d}^{-1}$ during the first days of life (3), and serves a dual role in fuel homeostasis: it serves in substrate delivery both for direct energy supply and for ketogenesis. Because of the precarious balance between neonatal glucose production and the almost equal glucose utilization requirements of the 400-g newborn brain (1), there is an absolute need for alternative fuels capable of sparing (or replacing) glucose for cerebral nutrition. Free fatty acids, while providing several tissues with readily oxidizable substrates, cannot cross the blood-brain barrier

Received for publication 8 April 1985.

J. Clin. Invest.

(c) The American Society for Clinical Investigation, Inc.

0021-9738/86/01/0042/07 \$1.00

Volume 77, January 1986, 42-48 to be utilized by the brain. However, their water-soluble derivatives, acetoacetate (AcAc) ${ }^{1}$ and 3-hydroxybutyrate (3-OHB), besides being used as fuel by tissues (4), have the unique capacity of replacing glucose for the energy needs of the central nervous system in humans (5). Since this capacity is already functional in the immature human brain (6-9), ketone bodies might play an important role in the caloric homeostasis of newly born infants. Furthermore, AcAc and 3-OHB are important precursors for the synthesis of structural lipids in the developing human brain (10). Whether fasted for the first $24 \mathrm{~h}$ of life $(11,12)$ or fed under current nursery practices $(3,13)$, newborn infants have a degree of ketosis that is achieved by the adult only after 1-2 d of total starvation (14). Nevertheless, there are no quantitative measurements of ketone body transport in the human newborn. Recently we developed a gas chromatography-mass spectrometry (GCMS) approach using nonradioactive, deuterium-labeled 3OHB tracer, which has allowed us to make these measurements in the human neonates in an ethically acceptable fashion. In addition, ketone body turnover was also measured in older infants (1-6 mo of age) to evaluate the quantitative importance of these substrates during short-term fasting.

\section{Methods}

Patients. Glucose and ketone body turnover rates were measured simultaneously in six newborns (group A) and four older infants (group B). In addition, one infant with insulin-dependent diabetes mellitus and another with hyperinsulinism were studied. The clinical characteristics of the infants are presented in Table I. Infants in group A were born at term and appropriate weight for gestational age, estimated from the date of the mother's last menstrual period and by physical examination (15). All infants were born after an uncomplicated pregnancy, but infant 5 had a low initial Apgar score responding to routine resuscitation. Four mothers had premature rupture of membranes and one mother had a temperature of $38.5^{\circ} \mathrm{C}$ during labor. Thus, five of the newborns studied were receiving intravenous antibiotic therapy, but in none was infection confirmed by culture. At the time of the study, all infants were asymptomatic, resting comfortably in an isolette or a crib, and covered with a blanket to avoid hypothermia during the study. Medical care of each newborn was under control of the child's physician who designated the infant's feeding schedule according to his routine nursery practice, so that none of the infants was specifically fasted for the purpose of the tracer experiment. Subjects 1 and 2 had received no oral feedings before the study. These two infants, and the four others treated with intravenous antibiotics, received intravenous dextrose at a "keep-open" rate of $<1$ $\mathrm{mg}$ dextrose $\mathrm{kg}^{-1} \mathrm{~min}^{-1}$. In each instance, the intravenous solution was switched to $0.45 \%$ saline a minimum of $3 \mathrm{~h}$ before starting the tracer experiment. Infants of Group B were referred patients: two of them because of suspected but undocumented hypoglycemia (and later proved to be normal infants on a metabolic and endocrine basis), and the two

1. Abbreviations used in this paper: AcAc, acetoacetate; $\left[{ }^{2} \mathrm{H}_{3}\right] \mathrm{AcAc},[4,4,4-$ ${ }^{2} \mathrm{H}_{3}$ ]acetoacetate; GCMS, gas chromatography-mass spectrometry; 3OHB, 3-hydroxybutyrate; $\left[{ }^{2} \mathrm{H}_{3}\right] \mathrm{OHB}, \mathrm{D}-(-)-3$-hydroxy $[4,4,4-$ ${ }^{2} \mathrm{H}_{3}$ ]butyrate. 


\begin{tabular}{|c|c|c|c|c|c|c|c|c|}
\hline Subjects & Sex & Gestational age & Weight & Weight & Postnatal age & $\begin{array}{l}\text { Time since } \\
\text { last feeding }\end{array}$ & History & Apgar scores \\
\hline & & $w k$ & $k g$ & percentile & $d$ & $h$ & & $1 \mathrm{~min} / 5 \mathrm{~min}$ \\
\hline \multicolumn{9}{|l|}{ Group A } \\
\hline 1 & $\mathbf{F}$ & 39 & 2.95 & 28 & 0.5 & 4.0 & Unremarkable & $6 / 8$ \\
\hline 2 & $\mathbf{M}$ & 40 & 3.50 & 72 & 0.5 & 6.5 & PRM* & $9 / 10$ \\
\hline 3 & $\mathrm{~F}$ & 38 & 2.45 & 15 & 1 & 5.0 & Maternal fever & $9 / 9$ \\
\hline 4 & $\mathbf{F}$ & 39 & 3.05 & 50 & 1 & 4.0 & PRM $^{*}$ & $4 / 7$ \\
\hline 5 & $\mathbf{M}$ & 39 & 2.99 & 26 & 2 & 4.0 & PRM* & $2 / 8$ \\
\hline 6 & $\mathbf{M}$ & 38 & 3.30 & 74 & 10 & 3.5 & PRM* $^{*}$ & $7 / 9$ \\
\hline \multicolumn{9}{|l|}{ Group B } \\
\hline 7 & $\mathbf{M}$ & & 3.90 & 10 & 50 & 8.5 & Suspected hypoglycemia & \\
\hline 8 & $\mathbf{M}$ & & 4.00 & 5 & 80 & 7.0 & Suspected hypoglycemia & \\
\hline 9 & $\mathbf{F}$ & & 4.25 & 2 & 126 & 7.5 & Mild viral diarrhea & \\
\hline 10 & $\mathbf{M}$ & & 6.60 & 5 & 200 & 7.5 & Mild viral diarrhea & \\
\hline \multicolumn{9}{|l|}{ Group C } \\
\hline 11 & $\mathbf{M}$ & & 7.42 & 50 & 165 & 3.0 & Hyperinsulinism $\ddagger$ & \\
\hline 12 & $\mathbf{F}$ & & 8.77 & 45 & 300 & 8.0 & IDM§ & \\
\hline
\end{tabular}

* PRM, prematurely ruptured membranes; $\ddagger$ Nesidioblastosis; $\S$ IDM, type I, insulin-dependent diabetes mellitus.

others because of viral diarrhea with weight loss $<10 \%$ of body weight. Thus, subjects 7 and 8 were fasted as part of routine evaluation for hypoglycemia, while subjects 9 and 10 had resumed normal feeding for 2-3 d before the study.

Infant 11 was referred to our clinic for hypoglycemia, which was proven to be due to insulin excess by a diagnostic fasting test that disclosed a rapid decrease of plasma glucose associated with increased plasma insulin concentration $(63 \mu \mathrm{U} / \mathrm{ml})$. The tracer study was performed during this fasting test.

Infant 12 had insulin-dependent diabetes mellitus previously treated using continuous subcutaneous insulin pump therapy (16). As part of a separate research protocol evaluating the potential risks of this therapy in very young children (16), and the metabolic consequences following abrupt interruption of the insulin infusion, this child's glucose and ketone kinetics were studied under close in-hospital medical control. The tracer study was thus started $2 \mathrm{~h}$ after pump therapy was discontinued.

Materials. D-(-)-3-hydroxy $\left[4,4,4-{ }^{2} \mathrm{H}_{3}\right]$ butyrate $\left(92 \%\right.$ atom $\left.\%{ }^{2} \mathrm{H}_{3}\right)$, and D-[6,6- $\left.{ }^{2} \mathrm{H}_{2}\right]$ glucose $\left(97\right.$ atom $\%{ }^{2} \mathrm{H}_{2}$ ) were purchased from Merck, Sharp and Dohme Canada, Ltd., Montreal, Quebec, Canada. Chemical and isotopic purity were confirmed by conventional enzymatic, gas chromatographic, and mass spectrometric analyses. Each preparation was pyrogen-free by standard rabbit body temperature measurements after intravenous administration according to federal guidelines in a licensed commercial laboratory. D-(-)-3-hydroxy $\left[4,4,4-{ }^{2} \mathrm{H}_{3}\right]$ butyrate and $\left[6,6-{ }^{2} \mathrm{H}_{2}\right]$ glucose were dissolved in $0.5 \mathrm{~N}$ saline and prepared for human use as described (1).

Procedural methods. Infants were studied after obtaining parental consent according to protocols approved by the Saint-Vincent-de-Paul and Institute National de la Santé et de la Recherche Médicale (INSERM) Committees on Ethics in Human Experimentation. In all of the newborns, and in infants 9 and 10, the peripheral intravenous "scalp vein" needle already in place for antibiotic or fluid administration was used for tracer infusion. In the remaining infants (numbers 7, 8, 11, and 12), a 25-gauge "scalp vein" needle was inserted into a peripheral vein at least $2 \mathrm{~h}$ before the onset of the tracer infusion.

At time zero of the study, we collected base-line samples (see below) and began continuous infusion of labeled tracers using a calibrated syringe pump at the rate of $0.266 \pm 0.025$ (SEM) $\mu \mathrm{mol} \mathrm{kg}^{-1} \mathrm{~min}^{-1} \mathrm{D}-(-)$ 3-hydroxy $\left[4,4,4-{ }^{2} \mathrm{H}_{3}\right]$ butyrate $\left(\left[{ }^{2} \mathrm{H}_{3}\right] \mathrm{OHB}\right)$ and $0.446 \pm 0.017 \mu \mathrm{mol} \mathrm{kg}{ }^{-1}$ $\min ^{-1} \mathrm{D}-\left[6,6-{ }^{2} \mathrm{H}_{2}\right]$ glucose. These rates of infusion were maintained for
$120 \mathrm{~min}$ in all studied infants. Before the start of the study, and every $10 \mathrm{~min}$ from 90 to $120 \mathrm{~min}, 500 \mu \mathrm{l}$ "heel stick" arterialized capillary blood samples were collected into iced heparinized tubes. Plasma proteins and blood cells were precipitated from separate $100-\mu \mathrm{l}$ and $300-\mu \mathrm{l}$ blood aliquots in preweighed iced centrifuge tubes containing 300 and $700 \mu \mathrm{l}$ of cold $10 \%$ perchloric acid, respectively, for subsequent measurement of substrate concentrations and ketone body isotopic enrichment (see below). Plasma from the remaining $100 \mu \mathrm{l}$ of blood was immediately separated by high speed centrifugation and kept frozen at $-20^{\circ} \mathrm{C}$ for subsequent measurement of glucose isotopic enrichment (see below).

An additional 200- $\mu$ l blood sample was obtained at the end of the study and the plasma was mixed with $800 \mu l$ of water and $3 \mathrm{ml}$ of Dole's mixture for subsequent measurement of free fatty acid (FFA) concentration. Urine was collected at the end of the study and for the following $2 \mathrm{~h}$ and kept frozen at $-20^{\circ} \mathrm{C}$.

Analytical methods. Blood glucose, acetoacetate, and D-(-)-3-hydroxybutyrate were measured spectrophotometrically by specific enzymatic micromethods (17) within $12 \mathrm{~h}$ after collecting blood samples. Isotopic enrichments in circulating $\left[{ }^{2} \mathrm{H}_{3}\right] \mathrm{OHB}$ and in $[4,4,4-$ $\left.{ }^{2} \mathrm{H}_{3}\right]$ acetoacetate $\left(\left[{ }^{2} \mathrm{H}_{3}\right]\right.$ AcAc) were measured by selected ion monitoring GCMS as recently described (17a). Briefly, after addition of blood, the perchloric acid supernatant was separated by high speed centrifugation and the $\mathrm{pH}$ was adjusted to $6.5-7.0$ with $10 \% \mathrm{KOH}$. Potassium perchlorate salts were precipitated and the remaining supernatant was acidified with $100 \mu l$ of $1 \mathrm{~N} \mathrm{HCl}$. The regenerated ketoacids were immediately extracted into ethylacetate and converted to their respective trimethylsilyl ester derivatives by treatment with $10 \%$ pyridine in $N, O$-bis-trimethylsilyltrifluoroacetamide. The resultant 3-OHB and AcAc trimethylsilyl esters were resolved by gas chromatography as described (17a). Computer controlled, electron impact, selected ion monitoring GCMS of the [M-15] ${ }^{+}$ ion clusters of both 3-OHB (m/z 233 and 236) and AcAc (m/z 231 and 234) representing the unlabeled ketone and its $\left[{ }^{2} \mathrm{H}_{3}\right]$ labeled tracer, respectively, allowed subsequent calculation of individual $\left[{ }^{2} \mathrm{H}_{3}\right] \mathrm{OHB}$ and $\left[{ }^{2} \mathrm{H}_{3}\right] \mathrm{AcAc}$ isotopic enrichments (17a). When infused simultaneously in rats, $\mathrm{D}-(-)-3$-hydroxy $\left[4,4,4-{ }^{2} \mathrm{H}_{3}\right]$ butyrate and $\mathrm{D}-(-)$-3-hydroxy $\left[3-{ }^{14} \mathrm{C}\right]-$ butyrate are partitioned to the same degree in acetoacetate and measure identical total ketone body turnover rates (17a).

To measure $\left[6,6-{ }^{2} \mathrm{H}_{2}\right]$ glucose enrichment, we added $50 \mu \mathrm{l}$ of plasma to $250 \mu \mathrm{l}$ of $0.3 \mathrm{~N}$ barium hydroxide and precipitated the proteins by adding $250 \mu \mathrm{l}$ of $0.3 \mathrm{~N}$ zinc sulfate. After centrifugation, the supernatant 
was subjected to sequential anion and cation exchange chromatography (1) and the neutral eluate was used to measure plasma $\left[6,6-{ }^{2} \mathrm{H}_{2}\right] \mathrm{glucose}$ enrichment by selected ion monitoring GCMS as described $(1,18)$. Plasma total FFA content was calculated from the summed individual fatty acid methyl ester gas chromatography peak areas referenced to heptadecanoic acid as internal standard (19).

Calculations. Blood total ketone body (AcAc + 3-OHB) inflow transport (or rate of appearance, $R_{\mathrm{a}}$ ), rate of outflow (or disappearance, $\left.R_{\mathrm{d}}\right)$, and clearance rate $\left(R_{\mathrm{c}}\right)$ were calculated from samples taken between 90 and 120 min of study. In all studied infants, both blood AcAc and 3-OHB content and the $\left[{ }^{2} \mathrm{H}_{3}\right]$ enrichment in each ketone remained reasonably constant $(\mathrm{SD} /$ mean $<0.15)$ and were considered at or near steady state. In this situation, treatment of kinetic data can be carried out either by the "single pool" approach (20-23), with blood AcAc and 3-OHB pools being lumped as one, or by the "two accessible pools" approach $(24,25)$ considering blood AcAc and 3-OHB pools separately.

There was rapid formation of $\left[{ }^{2} \mathrm{H}_{3}\right] \mathrm{AcAc}$ from $\left[{ }^{2} \mathrm{H}_{3}\right] \mathrm{OHB}$, with both ketones retaining the deuterium atoms in position 4 . Since, at steady state, $\left[{ }^{2} \mathrm{H}_{3}\right]$ AcAc enrichment averaged $67.1 \pm 3.5 \%$ (SE) that of the $\left[{ }^{2} \mathrm{H}_{3}\right] \mathrm{OHB}$ tracer, we considered that 3-OHB and AcAc were interconverted rapidly enough to minimize the error of considering them in the same pool. Barton (26) has shown that under the conditions of the current study (i.e., 3-OHB/AcAc concentration ratio of $\sim 2.7$ and $\left[{ }^{2} \mathrm{H}_{3}\right] \mathrm{OHB} /$ $\left[{ }^{2} \mathrm{H}_{3}\right]$ AcAc enrichment ratio $\sim 1.55$ ), relative error introduced by the use of the conventional "single pool" analysis for estimation of turnover rates and metabolic clearance of ketone bodies was no more than 10 $15 \%$ (26). Moreover, the constant infusion of $\left[{ }^{2} \mathrm{H}_{3}\right] \mathrm{OHB}$ tracer allows stochastic calculation of ketone body turnover rates, thereby avoiding a number of structural and computational assumptions that are not necessarily valid (27).

The $\left[{ }^{2} \mathrm{H}_{3}\right]$ enrichment of blood total ketone bodies $\left(\mathrm{E}_{\mathbf{k b}}\right)$ was calculated for each time point as follows:

$E_{k b}=E_{O H B} \times \frac{[3-O H B]}{[A c A c+3-O H B]}+E_{A c A c} \times \frac{[A c A c]}{[A c A c+3-O H B]}$,

where [3-OHB] and [AcAc] are the blood concentrations of the ketones, and $E_{O H B}$ and $E_{A C A C}$ are their $\left[{ }^{2} \mathrm{H}_{3}\right]$ enrichment values, respectively.
Total ketone body turnover rates were calculated from the following steady state equation as described (1):

$R_{\mathrm{a}}=R_{\mathrm{d}}=\left(\frac{\mathrm{E}_{i}}{\mathrm{E}_{\mathrm{kb}}}-1\right) \times i$,

where $i$ is the amount of infused tracer material and $E_{i}$ is the $\left[{ }^{2} \mathrm{H}_{3}\right]$ enrichment of the $\left[{ }^{2} \mathrm{H}_{3}\right] \mathrm{OHB}$ tracer.

Because each subject also achieved approximately constant values $(\mathrm{SD} /$ mean $<5 \%)$ for plasma glucose and $\left[6,6-{ }^{2} \mathrm{H}_{2}\right]$ glucose enrichment, similar steady state equations were employed for the calculation of glucose turnover rate, as described (1). Total FFA inflow and outflow transport rates were estimated from plasma FFA concentrations and the established linear relationship between plasma FFA content and transport in newborn infants (3).

\section{Results}

Substrate levels. Plasma substrates in the studied infants are presented in Table II. In group A, none of the newborns was hypoglycemic, although number 5 had a plasma glucose level at the lower normal limit at the time of the study. Neonatal blood AcAc and 3-OHB concentrations averaged 296 $\pm 112 \mu \mathrm{M}$ (SEM) and $486 \pm 67 \mu \mathrm{M}$, respectively, with a $3-\mathrm{OHB} / \mathrm{AcAc}$ concentration ratio of $3.0 \pm 1.0$. Total circulating ketone bodies were $781 \pm 172 \mu \mathrm{M}$. These values are in the range previously reported for newborns in their first days of life having a similar feeding schedule $(3,13)$. Plasma FFA level averaged $810 \pm 206 \mu \mathrm{M}$, a value in newborns that is similar to that previously reported by us for similar infants (3).

Infants of group B had blood total ketone body and FFA concentrations averaging $1,250 \pm 241 \mu \mathrm{M}$ and $956 \pm 110 \mu \mathrm{M}$, respectively, within or near normal physiological values for similarly fasted infants. The 3-OHB/AcAc concentration ratio was $2.70 \pm 0.03$, a normal value.

Infant 11 had a low plasma glucose $(43 \mathrm{mg} / \mathrm{dl})$ after only 3

Table II. Substrate Values During the Tracer Infusion Study

\begin{tabular}{|c|c|c|c|c|c|}
\hline Subject & Plasma glucose & Plasma FFA & Blood AcAc & Blood $\beta$-OHB & Blood total ketone bodies \\
\hline & $m g / d l$ & $\mu M$ & $\mu M$ & $\mu M$ & $\mu M$ \\
\hline \multicolumn{6}{|l|}{ Group A } \\
\hline 1 & $52 \pm 5$ & 824 & $187 \pm 20$ & $589 \pm 5$ & 776 \\
\hline 2 & $54 \pm 3$ & 1,802 & $136 \pm 15$ & $445 \pm 48$ & 581 \\
\hline 3 & $75 \pm 6$ & 498 & $736 \pm 32$ & $652 \pm 48$ & 1,388 \\
\hline 4 & $61 \pm 5$ & 546 & $531 \pm 15$ & $627 \pm 39$ & 1,158 \\
\hline 5 & $40 \pm 2$ & 700 & $153 \pm 19$ & $357 \pm 22$ & 510 \\
\hline 6 & $67 \pm 6$ & 489 & $32 \pm 1$ & $245 \pm 28$ & 277 \\
\hline Mean & 58 & 810 & 296 & 486 & 781 \\
\hline SE & 5 & 206 & 112 & 67 & 172 \\
\hline \multicolumn{6}{|l|}{ Group B } \\
\hline 7 & $90 \pm 3$ & 1,020 & $293 \pm 24$ & $937 \pm 16$ & 1,230 \\
\hline 8 & $75 \pm 2$ & 870 & $219 \pm 40$ & $549 \pm 38$ & 768 \\
\hline 9 & $66 \pm 4$ & 709 & $340 \pm 31$ & $751 \pm 81$ & 1,092 \\
\hline 10 & $64 \pm 2$ & 1,225 & $460 \pm 39$ & $1,451 \pm 146$ & 1,911 \\
\hline Mean & 74 & 956 & 328 & 922 & 1,250 \\
\hline SE & 6 & 110 & 51 & 193 & 241 \\
\hline \multicolumn{6}{|l|}{ Group C } \\
\hline 11 & $43 \pm 3$ & 356 & $87 \pm 2$ & $43 \pm 3$ & 130 \\
\hline 12 & $633 \pm 4$ & 631 & $663 \pm 86$ & $1,775 \pm 200$ & 2,438 \\
\hline
\end{tabular}


Table III. Ketone Body Transport

\begin{tabular}{|c|c|c|c|c|c|c|}
\hline Subjects & $\begin{array}{l}{\left[{ }^{2} \mathrm{H}_{3}\right] \mathrm{OHB}} \\
\text { enrichment }\end{array}$ & $\begin{array}{l}{\left[{ }^{2} \mathrm{H}_{3}\right] \mathrm{AcAc}} \\
\text { enrichment }\end{array}$ & $\begin{array}{l}\text { Total ketone } \\
\text { body enrichment }\end{array}$ & $\begin{array}{l}\text { AcAc/OHB } \\
\text { enrichment }\end{array}$ & $\mathbf{R}_{\mathbf{a}}$ & $\mathbf{R}_{\mathbf{c}}$ \\
\hline & atom $\%$ excess & atom \% excess & atom \% excess & $\%$ & 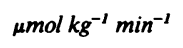 & $\mu \mathrm{mol} \mathrm{kg}{ }^{-1} \min ^{-1}$ \\
\hline \multicolumn{7}{|l|}{ Group A } \\
\hline 1 & $1.82 \pm 0.20$ & $1.13 \pm 0.06$ & 1.65 & 62.1 & 12.8 & 16.5 \\
\hline 2 & $0.80 \pm 0.11$ & $0.66 \pm 0.04$ & 0.77 & 82.3 & 21.9 & 36.6 \\
\hline 3 & $1.26 \pm 0.13$ & $0.89 \pm 0.12$ & 1.05 & 70.6 & 16.9 & 12.0 \\
\hline 4 & $1.65 \pm 0.18$ & $1.13 \pm 0.11$ & 1.42 & 68.5 & 18.0 & 15.5 \\
\hline 5 & $2.11 \pm 0.15$ & $1.50 \pm 0.11$ & 1.93 & 71.1 & 19.8 & 39.0 \\
\hline 6 & $1.50 \pm 0.06$ & $1.28 \pm 0.04$ & 1.47 & 85.0 & 14.2 & 51.0 \\
\hline Mean & 1.52 & 1.10 & 1.38 & 73.3 & 17.3 & 28.6 \\
\hline $\mathrm{SE}$ & 0.19 & 0.12 & 0.17 & 3.6 & 1.4 & 6.6 \\
\hline \multicolumn{7}{|l|}{ Group B } \\
\hline 7 & $1.16 \pm 0.10$ & $0.74 \pm 1.10$ & 1.05 & 64.0 & 17.9 & 14.6 \\
\hline 8 & $1.72 \pm 0.08$ & $1.00 \pm 0.06$ & 1.52 & 58.1 & 20.2 & 26.0 \\
\hline 9 & $1.50 \pm 0.02$ & $0.93 \pm 0.06$ & 1.32 & 62.0 & 18.3 & 16.8 \\
\hline 10 & $1.37 \pm 0.02$ & $0.64 \pm 0.01$ & 1.19 & 47.0 & 26.0 & 13.6 \\
\hline Mean & 1.44 & 0.83 & 1.28 & 57.8 & 20.6 & 17.8 \\
\hline $\mathrm{SE}$ & 0.11 & 0.08 & 0.09 & 3.8 & 0.9 & 2.8 \\
\hline \multicolumn{7}{|l|}{ Group C } \\
\hline 11 & $4.85 \pm 0.60$ & $2.25 \pm 0.30$ & 3.10 & 46.5 & 5.0 & 39.0 \\
\hline 12 & $0.62 \pm 0.05$ & $0.34 \pm 0.02$ & 0.54 & 55.0 & 32.2 & 13.1 \\
\hline
\end{tabular}

$h$ of fasting. At this time, circulating FFA (356 $\mu \mathrm{M})$ and ketone bodies $(130 \mu \mathrm{M})$ were abnormally low, while plasma insulin was present in excess $(63 \mu \mathrm{U} / \mathrm{ml})$.

Infant 12 , on the other hand, developed hyperglycemia $(633$ $\mathrm{mg} / \mathrm{dl})$, FFA mobilization $(631 \mu \mathrm{M})$, and dramatic ketosis $(2,438$ $\mu \mathrm{M})$ within only $4 \mathrm{~h}$ after her continuous subcutaneous infusion of insulin was interrupted.

Ketone body transport and its relationship with FFA and glucose transport. Table III presents the results of the $\left[{ }^{2} \mathrm{H}_{3}\right] \mathrm{OHB}$ tracer infusion study. During the study of group A and B subjects, infused $\left[{ }^{2} \mathrm{H}_{3}\right] \mathrm{OHB}$ tracer reached an overall average isotope enrichment of $1.50 \pm 0.12$ atom percent excess, whereas $\left[{ }^{2} \mathrm{H}_{3}\right] \mathrm{AcAc}$ enrichment averaged 1.0 \pm 0.09 atom percent excess. Thus, although complete isotopic equilibrium between the two ketones was not achieved, the value of the $\left[{ }^{2} \mathrm{H}_{3}\right] \mathrm{AcAc} /\left[{ }^{2} \mathrm{H}_{3}\right] \mathrm{OHB}$ enrichment ratio $(0.67 \pm 0.03)$ indicated extensive interconversion between blood 3-OHB and AcAc, resulting in an average $\left[{ }^{2} \mathrm{H}_{3}\right]$ enrichment of $1.34 \pm 0.1$ atom percent excess for blood total ketones in group A and B infants. During the last $30 \mathrm{~min}$ of study, the inflow-outflow transport rates of blood total ketone bodies were nearly identical in each subject population and averaged $17.3 \pm 1.4 \mu \mathrm{mol} \mathrm{kg} \mathrm{min}^{-1}$ in group A infants, and $20.6 \pm 0.93$ $\mu \mathrm{mol} \mathrm{kg} \mathrm{min}^{-1}$ in group $B$ infants, values not reached in adults until they are fasted for 3-23 d (14, 20, 23, 27-30). As expected, ketone body production was decreased in the hyperinsulinemic child (infant number 11), and increased in the diabetic child (infant number 12) after insulin withdrawal. There was a direct linear relationship $(r=0.8, P<0.002)$ between blood ketone level and rate of inflow-outflow transport (Fig. 1) as reported in adults over a similar range of blood ketone concentration (14, 21,23 ). Blood ketone body clearance rate ranged from 12 to 51 $\mathrm{ml} \mathrm{kg} \min ^{-1}$ (average, $28.6 \pm 6.6 \mathrm{ml} \mathrm{kg}^{-1} \min ^{-1}$ in group A, and $17.8 \pm 2.8 \mathrm{ml} \mathrm{kg}^{-1} \mathrm{~min}^{-1}$ in group B) and correlated nega- tively ( $r=0.87, P<0.001$ ) with blood ketone concentration (Fig. 2), as previously reported in fasted adults $(21,23)$.

From the infants' FFA values and the regression equation previously defined in a similar group of newborns (3), the plasma FFA inflow-outflow rate could be estimated for each infant ( $\mathrm{Ta}$ ble IV). FFA turnover averaged $14 \pm 2 \mu \mathrm{mol} \mathrm{kg} \mathrm{kg}^{-1} \mathrm{~min}^{-1}$ in the newborns, and $15 \pm 1 \mu \mathrm{mol} \mathrm{kg} \mathrm{min}^{-1}$ in group $B$ infants in

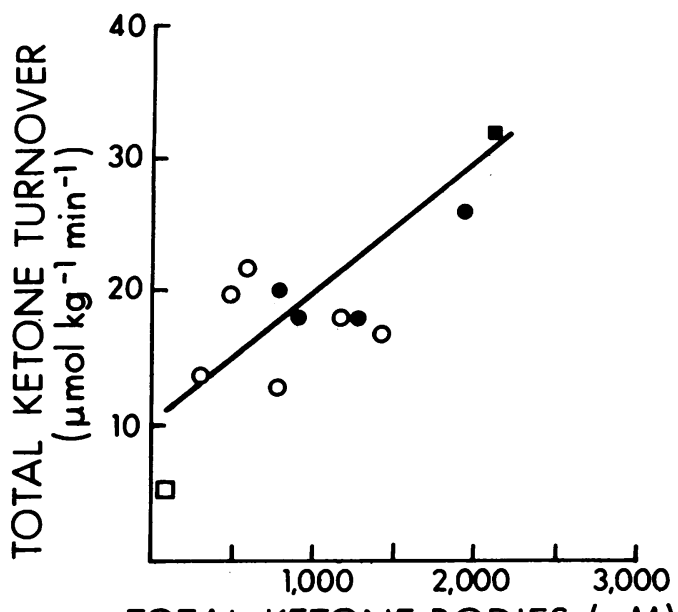

TOTAL KETONE BODIES $(\mu \mathrm{M})$

Figure 1. Relationship between blood total ketone concentration and total ketone body turnover rate in the infants studied. The open circles are group A infants; the closed circles are group B infants; the hyperinsulinemic child is depicted by an open square; and the diabetic child, by a closed square. The line is defined by the equation $Y$

$=0.009 X+10.5\left(r^{2}=0.64, P<0.002\right)$. In adults (references 14, 21, $23,28,29$ ), these relationships take the average form $Y=0.0042 X$ +4.1 . 


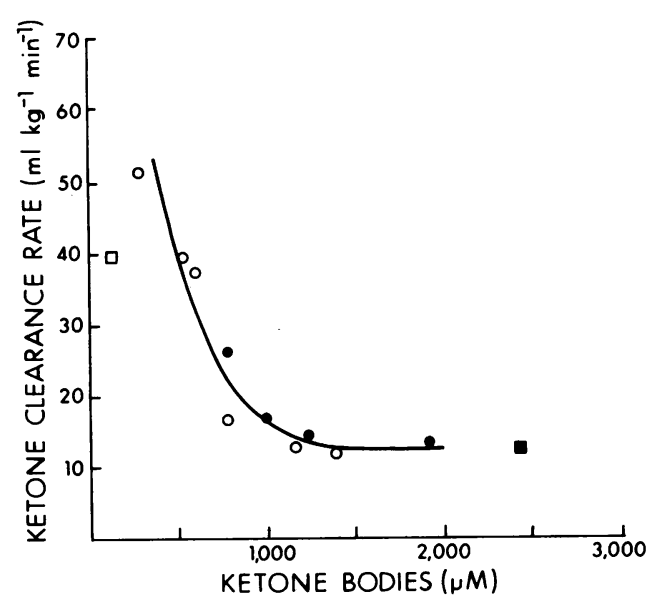

Figure 2. The relationship between ketone body concentrations and their clearance rates from blood in the infants studied. The symbols are the same as for Fig. 1.

good agreement with the value of $11.5 \pm 1.7 \mu \mathrm{mol} \mathrm{kg}^{-1} \mathrm{~min}^{-1}$ previously measured in neonates (3). Plasma FFA (and therefore FFA outflow rate) were correlated $(r=0.6, P<0.002)$ with ketone body production (Fig. 3) as anticipated from the precursor-product relationship between FFA and ketone bodies. Because the synthesis of $1 \mathrm{~mol}$ of AcAc or 3-OHB requires $\sim 0.25$ mol of plasma FFA, and assuming that all ketones are derived from FFA oxidation, the amount of FFA utilized for ketogenesis was estimated from ketone body production rate. Thus, $4.2 \pm 0.54$ $\mu \mathrm{mol} \mathrm{kg} \mathrm{min}^{-1}$ of FFA were converted to ketone bodies in group $\mathrm{A}$, and $5.2 \pm 0.5 \mu \mathrm{mol} \mathrm{kg} \mathrm{kg}^{-1} \mathrm{~min}^{-1}$ in group $B$ infants.
Therefore, the fraction of FFA flux that served for ketone body synthesis averaged $31 \pm 2 \%$, and was nearly constant in group $A$ and B infants. A smaller fraction (13\%) of FFA was directed toward ketogenesis in the hyperinsulinemic infant, and a larger one $(66 \%)$ in the diabetic; both results are consistent with insulin's role in ketogenesis. Glucose flux averaged $35.9 \pm 5.6 \mu \mathrm{mol} \mathrm{kg} \mathrm{kg}^{-1}$ $\mathrm{min}^{-1}$ in the group A infants and $27.5 \pm 1.6 \mu \mathrm{mol} \mathrm{kg}^{-1} \mathrm{~min}^{-1}$ in the group $B$ infants; both values are in agreement with those previously reported in the same age groups $(1,3)$. There was no significant relationship between glucose and ketone body respective transport rates. As again expected, infant 11 had decreased glucose production, as shown in other hyperinsulinemic children (28), and infant 12 with diabetes mellitus, had a dramatic increase of glucose turnover.

\section{Discussion}

Although ketone bodies are generally regarded as important metabolic fuels in the newborn infant $(31,32)$, we are not aware of direct measurement of their transport rates in this age group. This study shows that ketone body production and utilization are very active processes that occur at accelerated rates in term newborns, even when these neonates are fed every $4 \mathrm{~h}$ according to current nursery practices. The observed neonatal ketone body transport rates of $12.8-21.9 \mu \mathrm{mol} \mathrm{kg}^{-1} \mathrm{~min}^{-1}$, and those in older infants fasted for $\sim 8 \mathrm{~h}\left(17.9-26.0 \mu \mathrm{mol} \mathrm{kg} \mathrm{kg}^{-1} \mathrm{~min}^{-1}\right)$, are achieved by the adults only after several days of starvation (13, $21,23,28-30,33$ ). Because the newborn is currently fed on a basis of approximately every $4 \mathrm{~h}$, the total daily ketone body transport can, therefore, be estimated to be on the order of 2$3 \mathrm{~g} \mathrm{~kg}^{-1} \mathrm{~d}^{-1}$. In fasted adults, about $85 \%$ of ketone body production is oxidized, mostly in brain, muscle, and kidney (14).

Table IV. FFA and Glucose Turnover Rates

\begin{tabular}{|c|c|c|c|c|c|}
\hline Subjects & Estimated FFA turnover & FFA $\rightarrow$ Ketones & FFA $\rightarrow$ Ketones & {$\left[6,6-^{2} \mathrm{H}_{2}\right.$ ]glucose enrichment } & Glucose production rate \\
\hline & $\mu \mathrm{mol} \mathrm{kg}^{-1} \mathrm{~min}^{-1}$ & $\mu \mathrm{mol} \mathrm{kg}^{-1} \mathrm{~min}^{-1}$ & $\%$ & atom $\%$ excess & $\mu \mathrm{mol} \mathrm{kg}^{-1} \mathrm{~min}^{-1}$ \\
\hline \multicolumn{6}{|l|}{ Group A } \\
\hline 1 & 14 & 3.2 & 23 & $0.83 \pm 0.06$ & 51.8 \\
\hline 2 & 24 & 5.5 & 23 & $1.55 \pm 0.11$ & 25.8 \\
\hline 3 & 11 & 4.2 & 28 & $1.71 \pm 0.06$ & 25.3 \\
\hline 4 & 11 & 3.5 & 30 & $0.80 \pm 0.04$ & 50.8 \\
\hline 5 & 13 & 5.0 & 39 & $1.28 \pm 0.09$ & 40.9 \\
\hline 6 & 11 & 3.6 & 33 & $1.80 \pm 0.13$ & 20.9 \\
\hline Mean & 14 & 4.2 & 29 & 1.32 & 35.9 \\
\hline SEM & 2 & 0.4 & 3 & 0.18 & 5.8 \\
\hline \multicolumn{6}{|l|}{ Group B } \\
\hline 7 & 16 & 4.5 & 28 & $1.35 \pm 0.04$ & 30.0 \\
\hline 8 & 15 & 5.1 & 35 & $1.61 \pm 0.11$ & 24.5 \\
\hline 9 & 13 & 4.6 & 35 & $1.22 \pm 0.12$ & 30.6 \\
\hline 10 & 18 & 6.5 & 36 & $1.51 \pm 0.08$ & 24.8 \\
\hline Mean & 15 & 5.2 & 34 & 1.42 & 27.5 \\
\hline SEM & 1 & 0.5 & 2 & 0.09 & 1.6 \\
\hline \multicolumn{6}{|l|}{ Group C } \\
\hline 11 & 10 & 1.25 & 13 & $2.06 \pm 0.08$ & 18.6 \\
\hline 12 & 12 & 8.10 & 66 & $0.79 \pm 0.08$ & 71.2 \\
\hline
\end{tabular}




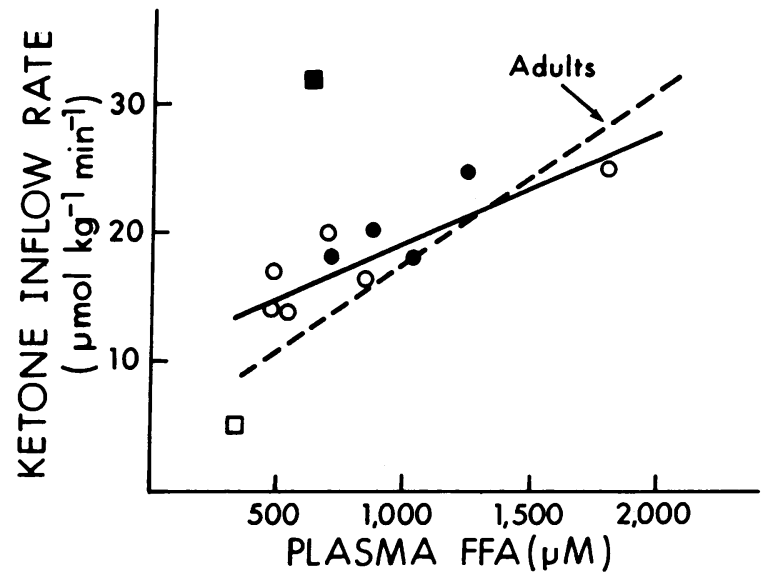

Figure 3. The relationship between plasma free fatty acid concentration and the plasma inflow rate $\left(R_{a}\right)$ of ketones in the studied infants. The symbols are the same as those for Fig. 1. The solid regression line calculated from the infant data is defined by the equation $Y$ $=0.0056 X+13.7$. The dotted line is calculated from averaged similar data in adults (references $14,21,23,28$ ) and has the function $Y=0.014 X+3.8$.

If one assumes the same fractional oxidation rate for the newborn, the neonate would oxidize $\sim 2 \mathrm{~g}$ of ketone bodies per kilogram body weight daily. This oxidation would yield the equivalent of $\sim 10 \mathrm{kcal} \mathrm{kg}^{-1} \mathrm{~d}^{-1}$, one-fourth of the minimal, basal energy requirements on the first days of life for an infant in a thermoneutral environment (34). Most importantly, at a time when glucose production is just sufficient to serve the demand of the newborn brain (1), ketone bodies can thus serve as alternate substrates for the oxidative requirement of the central nervous system. Recent in vivo studies of cerebral metabolism in infants confirm that the immature brain can utilize ketone bodies at rates of 3-8 $\mu \mathrm{mol} / 100 \mathrm{~g}$ brain weight per minute (6, $7,9)$, Thus, a $3.5-\mathrm{kg}$ term newborn with a $420-\mathrm{g}$ brain could extract 13-34 $\mu \mathrm{mol}$ of ketone bodies per minute (4-10 $\mu \mathrm{mol} /$ $\mathrm{kg}$ body weight per minute) to serve cerebral ketone body oxidation alone. The newborn's central nervous system then might consume approximately one-fourth to one-half of daily hepatic ketone body output in neonates and young infants.

As in the adult $(21,23)$, ketone levels in our infants were directly correlated with outflow transport (Fig. 1) and inversely correlated with metabolic clearance rate (Fig. 2). However, both outflow transport and clearance rates were about two times greater in newborns and young infants than in adults having similar ketone body levels $(14,21,23)$. This increased capacity for taking up ketone bodies from the blood stream in the neonate is consistent with its large brain size in relation to total body weight, and the fourfold increase in neonatal cerebral ketone body uptake compared with the adult $(6,9)$. The close agreement between the regression equation for ketone body production and FFA levels in our patients and the regression calculated from data presented in adult studies $(14,21,23,28)$ (Fig. 3) is supported by the similar fraction $(\sim 30 \%)$ of the FFA flux, which is converted into ketones (35). These similar relationships, taken together with the ability of the neonate to produce large amounts of ketones, suggest that ketogenesis is already mature in humans on the first day of life, and that the intrahepatic and extrahepatic regulatory systems controlling the conversion of FFA into KB are well established by this early postnatal age.

\section{Acknowledgments}

We wish to thank the physicians who gave us access to their patients for these studies, the families for consenting, and the nurses at Hôpital St. Vincent de Paul for their assistance and excellent care of the study subjects.

This study was supported in part by research grants from Institute National de la Santé et de la Recherche Médicale and National Institutes of Health (HD10667 and RR00954).

\section{References}

1. Bier, D. M., R. D. Leake, M. W. Haymond, K. J. Arnold, L. D. Gruenke, M. A. Sperling, and D. M. Kipnis. 1977. Measurement of "true" glucose production rates in infancy and childhood with 6,6 didueteroglucose. Diabetes. 26:1016-1023.

2. Van Duyne, C. M., and R. J. Havel. 1959. Plasma unesterified fatty acid concentration in fetal and neonatal life. Proc. Soc. Exp. Biol. Med. 102:599-602.

3. Bougneres, P. F., I. E. Karl, L. S. Hillman, and D. M. Bier. 1982. Lipid transport in the human newborn. Palmitate and glycerol turnover and the contribution of glycerol to neonatal hepatic glucose output. $J$. Clin. Invest. 70:262-270.

4. Robinson, A. M., and D. H. Williamson. 1980. Physiological roles of ketone bodies as substrates and signals in mammalian tissues. Physiol. Rev. 60:153-187.

5. Owen, O. E., A. P. Morgan, H. G. Kemp, J. M. Sullivan, M. G. Herrera, and G. F. Cahill, Jr. 1967. Brain metabolism during fasting. $J$. Clin. Invest. 46:1589-1595.

6. Persson, B., G. Settergren, and G. Dahlquist. 1972. Cerebral arteriovenous difference of acetoacetate and D- $\beta$-hydroxybutyrate in children. Acta. Paediatr. Scand. 61:273-278.

7. Kraus, H., S. Schlenker, and D. Schwedesky. 1974. Developmental changes of cerebral ketone body utilization in human infants. HoppeSeyler's Z. Physiol. Chem. 355:164-170.

8. Adam, P. A. J., N. Raiha, E. L. Rahiala, and M. Kekomaki. 1975. Oxidation of glucose and $\mathrm{D}-\beta$-OH-butyrate by the early human fetal brain. Acta. Paediatr. Scand. 64:17-24.

9. Settergren, G., B. S. Lindblad, and B. Persson. 1976. Cerebral blood flow and exchange of oxygen, glucose, ketone bodies, lactate, pyruvate and amino acids in infants. Acta Paediatr. Scand. 65:343-353.

10. Patel, M. S., C. A. Johnson, R. Rajan, and O. E. Owen. 1975. The metabolism of ketone bodies in developing human brain: development of ketone-body-utilizing enzymes and ketone bodies as precursors for lipid synthesis. J. Neurochem. 25:905-903.

11. Melichar, V., V. Drahota, and P. Hahn. 1967. Ketone bodies in the blood of full term newborns, premature and dysmature infants and infants of diabetic mothers. Biol. Neonat. 11:23.

12. Persson, B., and J. Gertz. 1976. The pattern of blood lipids and ketone bodies during the neonatal period, infancy and childhood. Acta Paediatr. Scand. 55:353-362.

13. Anday, E. K., C. A. Stanley, L. Baker, and M. Delivoria-Papadopoulous. 1981. Plasma ketones in newborn infants: absence of suckling ketosis. J. Pediatr. 98:628-630.

14. Reichard, G. A., Jr., O. E. Owen, A. C. Haff, P. Paul, and W. M. Bortz. 1974. Ketone-body production and oxidation in fasting obese humans. J. Clin. Invest. 53:508-515.

15. Dubowitz, I., V. Dubowitz, and C. Goldberg. 1970. Clinical assessment of gestational age in the newborn infant. J. Pediatr. 77:1-10.

16. Bougneres, P. F., F. Landier, C. Lemmel, A. Mensire, and J. L. Chaussain. 1984. Insulin pump therapy in young children with Type I diabetes. J. Pediatr. 105:212-217.

17. Williamson, D. H., and J. Mellanby. 1974. In Methods of Enzymatic Analysis. H. U. Bergmeyer, editor. Academic Press, Inc., New York. 1836-1843.

17a. Bougneres, P. F., E. O. Balasse, P. Ferre, and D. M. Bier. 1986. Determination of ketone body kinetics using a D-(-)-3-hydroxy[4,4,4${ }^{2} \mathrm{H}_{3}$ ]butyrate tracer. Lipid Res. In press. 
18. Bougneres, P. F., P. Ferre, J. L. Chaussain, and J. C. Job. 1982. Glucose metabolism in hyperinsulinemic infants: the effects of fasting and DL- $\beta$-hydroxybutyrate on glucose production and utilization rates. J. Clin. Endocrinol. Metab. 57:1054-1060.

19. Galster, A. D., W. E. Clutter, P. E. Cryer, J. A. Collins, and D. M. Bier. 1981. Epinephrine plasma thresholds for lipolytic effects in man: measurement of fatty acid transport with $\left[1{ }^{13} \mathrm{C}\right]$ palmitic acid. $J$. Clin. Invest. 67:1729-1738.

20. Bates, M. W., H. A. Krebs, and D. H. Williamson. 1968. Turnover rates of ketone bodies in normal, starved and alloxan-diabetic rates. Biochem. J. 110:655-661.

21. Fery, F., and E. O. Balasse. 1985. Ketone body production and disposal in diabetic ketosis: a comparison with fasting ketosis. Diabetes. 34:326-332.

22. McGarry, J. D., M. J. Guest, and D. W. Foster. 1970. Ketone body metabolism in the ketosis of starvation and alloxan diabetes. $J$. Biol. Chem. 245:4382-4390.

23. Balasse, E. O. 1979. Kinetics of ketone body metabolism in fasting humans. Metabolism. 28:41-50.

24. Rescigno, A., and E. Gurpide. 1973. Estimation of average times of residence, recycles, and interconversion of blood-borne compounds using tracer methods. J. Clin. Endocrinol. Metab. 36:263-276.

25. Barton, R. N. 1973. The interconversion and disposal of ketone bodies in untreated and injured post-absorptive rates. Biochem. J. 136: 531-543.

26. Barton, R. N. 1980. Isotopic study of ketone body kinetics: invalidity of calculations based upon specific radioactivity of total ketone bodies. Metabolism. 29:392-394.
27. Berman, N. 1979. Kinetic analysis of turnover data. Prog. Biochem. Pharmacol. 15:67-108.

28. Balasse, E. O., F. Fery, and M. A. Neef. 1978. Changes induced by exercise in rates of turnover and oxidation of ketone bodies in fasting man. J. Appl. Physiol. 44:5-11.

29. Cobelli, C., R. Nosadini, G. Toffalo, A. McCulloch, A. Avogaro, A. Tiengo, and K. G. M. M. Alberti. 1982. Model of the kinetics of ketone bodies in humans. Am. J. Physiol. 243:R7-R17.

30. Keller, U., G. E. Sonnenberg, and W. Stauffacher. 1981. Validation of a tracer technique to determine nonsteady-state ketone body turnover rates in man. Am. J. Physiol. 240:E253-E262.

31. Hahn, P. 1978. Lipids. In Perinatal Physiology. U. Stave, editor. Plenum Publishing Corp., New York. 397.

32. Hull, D. 1975. Storage and supply of fatty acids before and after birth. Br. Med. Bull. 31:32.

33. Owen, O. E., M. S. Patel, and G. Boden. 1978. Ketone body metabolism in humans during health and disease. In Biochemical and Clinical Aspects of Ketone Body Metabolism. H. D. Soling and S. D. Seurfert, editors. Thieme Publishers, Stuttgart, Federal Republic of Germany. 155-165.

34. Sinclair, J. C. 1976. Metabolic rate and temperature control. In The Physiology of the Newborn Infant. C. A. Smith and N. M. Nelson, editors. Charles C. Thomas, Publisher, Springfield, IL. 354-415.

35. Owen, O. E., P. Felig, A. P. Morgan, J. Wahren, and G. F. Cahill, Jr. 1969. Liver and kidney metabolism during prolonged starvation. $J$. Clin. Invest. 48:574-583. 